\title{
Methodologies and problems in zoomusicology
}

\author{
Dario Martinelli \\ Department of Musicology, University of Helsinki \\ Vironkatu 1, 00014 Helsinki, Finland \\ e-mail: dario.martinelli@helsinki.fi
}

\begin{abstract}
The article sketches an introductory outline of zoomusicology as a discipline closely related to zoosemiotics, focusing on the existing results and formulating few further problems. The analysis addresses the limitations and potentials of zoomusicological research, problematic topics, a basic framework of possible methodologies, and an attempt to situate the discipline in relation to other fields, ethnomusicology in particular.
\end{abstract}

\section{The role of zoomusicology}

Zoomusicology is a very young discipline. If the first appearance of the word ornithomusicology is dated 1963, thanks to Peter Szöke, zoomusicology is a much younger term, coined in F. B. Mâche's Music, Myth, Nature in 1992. It seems clear that most approaches to the discipline, and to others concerning animals, show strong signs of anthropocentrism. If science aspires to impartiality and exactitude, then these fields of science should try to avoid such a tendency. More properly, any study concerning animals should lean toward "biocentrism".

This does not mean that humans should turn into salmon. When geocentric theories were replaced by heliocentrism, scholars did not move from the earth to the sun in order to observe the motion of our planet. They just considered it as a part of something much bigger, stressing the similiarites earth shared with other planets, and seeing causes, effects, side effects and so on. The same should be done in the study of the animal kingdom: the point is no longer to consider humans as an autonomous category, but as a "planet" in the natural sys- 
tem. This does not mean restricting humans to an improper and uncomfortable cage. It is simply that every human characteristic should be considered as result of a wider process. In zoomusicology, nobody would ever say that electric guitars are played also by frogs, or that penguins buy CDs. But if we consider the biological dimension of what we call music, taking account of causes (anatomy, physiology, psychology, ethology, etc.), effects (timbres, intervals, form, organisation of the sounds, etc.) and side effects (rituals, movements, exchange of information, etc.), then the work becomes realistic and useful. Any interesting step forward in the study of animals can be done only through such a mentality, i.e., by turning from an anthropocentric outlook to a biocentric one. This implies the following.

(1) Nature is divided into levels that are organised as follows. Beyond a general common basis, here called ecological, whose constraints — such as being subject to gravity — are shared by everything on Earth, we have a second, biological level, in which every living being is included. Eating and reproducing, for instance, typify humans and birds, insects and flowers, and so on. Things become more interesting on the third level, called the zoological or the transpecific, which concerns aspects held in common within the whole animal kingdom. At this point, more than one human conception should be revised. It has been shown, for instance, that culture is not an exclusively human peculiarity. It is just a matter of complexity. In turn, complexity is a relative concept, since it should be proportioned to the respective needs of each species, what Uexküll called Umwelt. Fourthly, we come to the level of characteristics that concern a single species (species specific). Activities such as making a presentation with the use of transparencies must be considered exclusively human skills, just as giving the exact position of a flower by a figure-eight dance is a skill specific to bees. From the next level on, the course is quite clear for humans, but is yet to be well defined for other species. This is because the categories are now species-specific, and each species has developed a unique process. For most animals, including humans, this level is mainly social, but many species are not organised into societies at all. And so we should stop here.

(2) In this research, the transpecific level must be considered the first meaningful category. Zoomusicology is concerned with all those musical features that are not exclusive to humans, but are shared with at least some other species, specifically, among those provided with vocal apparatuses. It can be said that, as a zoological phenomenon, music can no longer be analysed from an anthropocentric point of 
view, just decades ago ethnomusicologists said that, as an anthropological phenomenon, music should not be analysed from a Eurocentric point of view.

(3) The species-specific level is so capacious that nobody should take this kind of research as being too zoomorphic. Homo sapiens retans its incredibly large number of exclusive aspects. The problem here is to arrange categories in the right position and proportions, and to create a more appropriate "cosmology".

(4) As Nils Wallin (1991) and other biomusicologists maintain, the study of music in its biological dimension can be very useful for the comprehension of its real essence and development.

\section{First problematic topic: Aesthetics}

To define zoomusicology in a few words, we can say that this discipline studies the "aesthetic use of sounds among animals". This definition would have the following consequences: (1) we would avoid the use of that really dangerous word, "music"; (2) we would include another dangerous word, "aesthetic", a concept that nonexperts would hardly extend to non-human animals; (3) by simply saying "animals", and not "non-human" ones, we would leave open the possibility of including those not made

The preference for the word "aesthetic", at this very generic stage, is motivated by the fact that this expression represents a methodological presupposition, whereas the expression "music" constitutes the real theoretical goal. In fact, whereas ethology, especially recently, tends to acknowledge the existence of an aesthetic sense in animals, concepts like musicality and musical culture still have too strong an anthropological connotation to be applied to the rest of the animal kingdom as well. Space does not permit a philosophical discussion of the essence of aesthetics and its evolution through the centuries. But five main aspects can be pointed out.

(1) We agree with Charles Hartshorne (1973: ch. 2) that, at a very biological level, aesthetic does not stand for something merely utilitarian. This does not mean that an aesthetic act is totally useless - too many people say that without music they couldn't survive! Rather, it means that the "biological effects" cannot be seen immediately, as happens, for instance, with coupling. This notion of aesthetics may be rather incomplete, but it points out a fundamental presupposition: aes- 
thetics is what makes the difference between a "sentence" and a "verse", or between "speaking" and "singing", and so on. At the same time, such a concept collides with the general non expert opinion that only humans are able to do non utilitarian things. Fortunately, however, since the times of Darwin and especially in the latest decades, many studies on animal behaviour have proved that this is not true.

(2) The word "aesthetic" has a clear connection with a certain sense of "beauty", a sensation that gives the individual who feels it a particular pleasure, be it emotional, intellectual, or cultural. This matter, too, has received much attention over the centuries, and in a way is similar to the previous point: "beauty" is what makes the difference between two non utilitarian forms of behaviour, such as painting as opposed to turning over the pages of a book.

(3) In semiotic terms, the definition of "aesthetics" provided by Roman Jakobson constitutes the perfection of simplicity: to Jakobson, language has an aesthetic function when it is more concerned with signifiers rather than with signifieds. As zoosemiotician Felice Cimatti (1998: 99) puts it: "The signified does not have an explicit function, and the organisation of the signifier is led by processes and rules intentionally 'blind', i.e., they have no aim but to match the various parts of the message".

(4) As Aristotle pointed out about tragedy (see Poetics), aesthetic messages have to be at the same time parà tèn dóxan (i.e. unexpected, contrary to common beliefs) and katà tò eikòs (i.e., likely, believable). In Eco's (1968) words, aesthetic messages must be ambiguous.

(5) Still, according to Eco (1968), aesthetic ambiguous information may be decoded in consequence of three factors: (a) signifiers acquire signifies only from contextual interaction; (b) the matter of signifiers is not totally arbitrary as regards the signifies (e.g., onomatopoeic words); (c) the message involves many levels of reality (e.g., physical matter of the signifiers, denotation meanings, connotation and so on).

A good illustration of these five concepts is the behaviour of the male Ptilonorhynchus violaceus during the preparation of his nest. ${ }^{1}$ This bird decorates the outside and inside of the place with colourful flowers, pebbles, twigs, and several human objects (such as bottle caps), and then applies a special paint he has obtained by chewing some ber-

${ }^{1}$ In fact, "nest" is not the right word, because it is not the place where the eggs are laid. The ethological term is "pergola", but the ideal one would be garçonnière, since this is where the coupling occurs. 
ries. As Mainardi reports (1992: 226), the bird chooses carefully the position of the decorations. He can be seen putting a flower atop the nest, taking a couple of steps backwards to assess his work, then deciding that the flower does not look nice in that place and changing its position until he's satisfied. Note that, once a flower withers, the bird replaces it with a new one. As a conclusion, the male invites the female to his nest by holding another flower in his beak, in a very flamenco fashion! The bird displays modes of behaviour that:

(1) are definitely not straightly utilitarian, since the bird could easily adopt more economic strategies of courtship;

(2) reveal certain sense of beauty, and not only in a human criteria, otherwise the bird wouldn't change position to that flower at the top of the pergola;

(3) are much more concerned with signifiers than usually, since a withered flower - functionally speaking — would contribute to the contents (the pergola's construction) in the same way as the newer one;

(4) are unexpected (at least to our eyes, but surely also to the female, since she's said to choose her partner according to how much he's able to impress her) and likely at the same time (the female must recognise the pergola as such);

(5) are decoded according to the above mentioned three factors as pointed out by Eco (1968), e.g., involving many levels of that reality.

Theodosius Dobzhansky observes: "It is undeniable that a welldecorated pergola gives the bird a pleasure that can only be defined as aesthetic" (1962: 215). A final remark leads the discussion to the next topic: when the pergolas were first discovered, ${ }^{2}$ it was thought that they were dollhouses built by young girls.

\section{Second problematic topic: Etic or emic?}

Methodologically, the main problem is how to approach such peculiar musical cultures. How can we be so bold as to use the word "music"? And in what sense? Ethologists have attempted to define the word "song" in terms of structure (for instance, Busnel 1963: Ch. 1), but to

\footnotetext{
${ }^{2}$ Pergolas were first noticed in the nineteenth century in Australia by the Italian naturalist Ottaviano Beccari.
} 
analyse music in and of itself is a little misleading. ${ }^{3}$ As Gino Stefani has demonstrated, the connection between a musical object and an individual person, who is able to think and to feel, cannot be disregarded. The point is not only our disposition, as humans, to consider animal sounds as music, but to see if such a conception exists within the animals group we are observing. In Nattiez's words, an emic approach is preferable to an etic one. ${ }^{4}$

Such an attitude is not easy even when studying a human community. How would this be possible as concerns animals? Everything we say is based on human criteria, which we would be arbitrarily applying to animals, since nobody could ever say if animals really think in the ways we think they do. This is, more or less, the position expressed in Thomas Nagel's famous article, "What is it like to be a bat?" (1974), which emphasises the basic incapacity of an objective and impersonal scientific approach to the description of subjective and private phenomena. Felice Cimatti's Mente e linguaggio negli animali aims to clarify this issue:

I believe that such a distinction is incorrect. Basically because it presupposes a dualism which is exactly what should be demonstrated, i.e. the dualism between mind and body, and between personal and impersonal perspective. I perceive my mind, from the inside, only through external ways: that is the thesis I am defending (as far as I know, the idea comes from Peirce and from the Soviet psychologist Vygotskij). (Cimatti 2000, personal communication)

Such a problem is common to most human sciences. Even with human cultures, and especially with so-called primitive societies, to take an emic approach is not easy. Ethnomusicology is very representative in this sense. Ethnomusicologists find sound structures, correlated behaviours, and emotional experiences that together look more or less like what we call music. Sometimes those cultures have a word (a content-form) that corresponds to our "music"; sometimes not. Some-

3 In ethology, there are some conditions to respect before using that word for an animal vocalisation. It was Broughton who laid down these conditions. By using human indicators, he found in animal sounds three application levels of the term 'song': sensu latissimo, sensu stricto, and sensu strictissimo.

${ }^{4}$ The terms etic and emic come from linguistics: etic is borrowed from phonetics (the study of linguistic sounds without regard to their significance within a language), and emic comes from phonemics (the study of speech sounds that are meaningful within a language). For more details about ethnomusicological application of these terms, see Nattiez (1977: 92-104) and Nettl 1956. In brief, if we judge a musical element of a different civilisation with our criteria, we are taking an etic approach; if we try to get inside that culture's own point of view, that would be an emic attitude. 
times there is one word for two or more different concepts (typically, music and dance or singing and speaking), and so on. In each case, however, we trust that those elements, attitudes and feelings belong to the same sense of the whole that we call "music". This is so not only because of their mutual likeness; it is also the case because they come from someone who has thoughts, feelings, an aesthetic sense, social attitudes, customs, and whatever we construe as related to the production of music. In a way, these features are used as indexical signs for music, and, in Peircean terms, very similar to "abduction". 5

Hence, there is little reason to deny such a skill to other animals. The contributions of ethologists and psychologists have nearly confirmed that animal behaviour is drastically far from Descartes's views. ${ }^{6}$ We are no longer shocked when someone uses the terms "culture", "emotions", and "reasoning" in reference to animals, and we should approach animals as if they were an "early tribal" society quite different from, but in no way inferior to, that of western civilisation. In that case, a totally etic attitude wouldn't be fair, and a totally emic one would hardly be possible. The compromise is what we would cautiously suppose to be an emic approach, based on similarity in rules, rituals, structures and so on. In more than one case, humans and other animals share plenty of musical traits and paramusical forms of behaviour: non humanity is not a good justification for musical anthropocentrism.

\section{Third problematic topic: Music}

Before further discussion about any kind of musical culture, we should establish what we mean by "music", in order to share the same conception of it. And this is a difficult question, as Giannattasio points out:

The absence of synonyms and the consequent polysemy of the term show how, to the majority of people, the whole of "musical" behaviours is like an endless, indefinite and much fascinating nebulosity, especially to who feels ignorant about it ("Lucky you expert! I do not know anything about music!").

${ }^{5}$ As Umberto Eco puts it, in abduction, "we find a very peculiar circumstance that could be explained by supposing that it is the specific case of a general rule, and consequently we adopt this supposition" (Eco 1975: 185).

${ }^{6}$ For more on the anti-Cartesian view of animals, see Masson and McCarthy (1996), Mortenson (1987), Darwin (1871, 1872), Ditadi (1994), Soriau (1965), and Mâche (1992). 
To the self-styled expert ones, "music" is something open to the smallest ("Nice performance, but there wasn't any musical expression in it") and the largest changes ("You can't call music that vulgar and noisy mess"). (Giannattasio 1992: 30)

As a proof of the difficulty, we note that most musical dictionaries do not include the term; just general dictionaries do, and their definitions tend to be overly generic. ${ }^{\text {? }}$

Of course, if such a definition is not shared within a so-called musical culture, we can turn to an inter-cultural context:

[...] a second difficulty encountered in an attempt to provide a universal definition [is] the absence of the concept of "music" in many cultures, and, more to the point, the fact that various cultures of the world classify the world of sound in many different ways. What may be singing to us in Europe and North America may be "reciting" or "reading" in an Islamic culture; what is birdsong to us may be "music" in an African culture; what is a composition to us may be a non-musical exercise model elsewhere; and so on. (Nettl 1977: 3)

Once more, we wonder if it is possible to define a concept like "music" in itself, which concerns only the musical object. ${ }^{8}$ Luca Marconi is undoubtedly right when he says: "What makes us recognise the presence of music are not only traits connected to some qualities of the sounds, but also traits connected to visible forms of behaviour and consequent experiences" (Marconi 1996: 89).

In sum, to formulate a "precise" definition of music is not possible. Such a definition would be identified by so-called necessary and sufficient features, and it would be characterised by one closed category of the term, as in a dictionary: we call "music" always and only something which has features a, b, and c. Just b and c would not be enough, and $\mathrm{a}, \mathrm{b}, \mathrm{c}$ and d would be too much. More realistic is what Wittgenstein would call a prototypical category definition: the more we have the a, b, etc. features, the more we have good examples of music. ${ }^{9}$ The main characteristic of this definition is centrality: some examples "work" better than others. Eleanor Rosch has shown that, to most people, a sparrow is a better example of a "bird" than a penguin is

${ }^{7}$ Typical dictionary definitions of music are inevitably partial and too restrictive; for example, "sounds organised to have melody, rhythm, harmony, and dynamics", or "an art of sounds in time that expresses ideas and emotions in significant through the elements of melody, rhythm, harmony, and dynamics".

${ }^{8}$ It should be recalled that the ancient Greek term mousiké, which is the supposed origin of the modern word music, is a concept that includes both music and poetry.

${ }_{9}$ This distinction already exists in most recent studies about categorisation. See, for instance, Rosch and Lloyd (1978), Kleiber (1990). 
(Rosch, Lloyd 1978). Zoologically, however, that view would be incorrect. Yet we intuitively see the sense in it. Likewise, Mozart's Eine Kleine Nachtmusik is surely a better example of music than are some of Berio's Sequenzas, but this does not mean that the former piece is music and the latter ones are not. Only Giannattasio's "self-styled experts" claim to set the limits, and, fatally, these limits tend to include the features "classical", "western", "academic", "operatic", and to exclude the features "popular", "non western", "light", "oral" (Giannattasio 1992: 31). Thus, this prototypical category definition of music should be meant when one uses the word "music" in zoomusicological contexts. This is not because that is the definition that best fits animals, but because it is the only one that allows us to share the same concept when we pronounce the word "music".

\section{Transpecific and species specific features}

If we assume that the word music, according to the characteristics mentioned above, can be easily used in a zoomusicological context (thus justifying the name of the discipline itself), the next step is to define the areas of analysis that zoomusicology can investigate. First of all, as mentioned above, a distinction should be made between transpecific and species specific features. "Transpecific" refers to those elements that can be found in more than one species, even if they are just a few. This level is important to show the biological common bases of musicality, and is definitely less problematic than the second level, since in most cases the analysis reveals great familiarity between the species observed and the human musical culture. The most trivial example is of course singing, but other, more particularized aspects - such as putting sounds in a graduated scale (Mâche 1992; Schafer 1985; Martinelli 1999) can also be put into evidence.

Elements are called species specific when they present characteristics that are typical of the species observed. This level shows how musicality, notwithstanding the above-mentioned biological basis, has taken quite varied courses, according to the evolution of each species. Of course, the less a species exhibits human musical traits, the more difficult musicological analysis becomes. This is because zoomusicology is just taking its first steps, such that human musicality, for the moment represents the only complete point of reference. When musical cultures of other animals have been studied more closely, we will 
probably be able - through the process of abduction - to create new musical parameters to apply to the most peculiar cases. A typical example of a species-specific trait is the number and quality of pertinent sounds and intervals during a performance. The perception and use of these pertinences varies from species to species, so that a sound that is catchy and pleasant to a dolphin's ear might sound totally out of tune to a seagull.

\section{Conclusion: Structures, processes, experiences}

In closing, allow me to point out one further similarity between zoomusicology and ethnomusicological research. It is an analytical grid that is very common in the study of musical universals, and that might prove useful in zoomusicological research as well.

(1) Structures: the musical traits in themselves, what Nattiez would call the neutral level. Analysis of this level implies a large use of sound material, such as recordings and spectrograms, and aims to define the organisation of sounds in the species observed; e.g., range of sounds covered, recurrent intervals, timbres, and so on. Mâche (1992) proposes exactly this kind of typological research.

(2) Processes: acts and behaviours related with the structures, in the fields of emission and reception. We could call this the world of the paramusical, and it includes the whole cultural dimension of making music, with its rituals, social rules and so on. This level constitutes the best-known part of zoomusicological research, with many of its aspects already investigated by ethology. The same kind of analysis can be found in Sebeok's Play of Musement (1981), in the section entitled "Musical Signs".

(3) Experience: this is the level that scholars like Stefani, Delalande and Tagg have proposed in the discussion about musical universals. Since musical experiences may be considered as a general human experience taking place between a subject (man or woman) and an object (musical event), they advanced the idea that a universal feature in each experience is the restatement of particular conducts and competencies. With similar presuppositions, this view may be used for zoomusicological purposes. If the first level was that of the objective, and the second was that of the cultural, this one is surely the level of subjectivity, the investigation of music as an experience lived by an individual (although it is clear that many of these experiences follow 
general rules). Tagg's (1987) bioacoustic relations, for instance, were a very interesting application of this level in my work on humpback whales (Martinelli 1999). Finally, let me say that I hope my introduction to zoomusicology has been convincing enough to prompt further study — at least by the would-be pioneers among us.

\section{References}

Busnel, Renae Guy (ed.) 1963. Acoustic Behavior of Animals. London: Elsevier. Cimatti, Felice 1998. Mente e linguaggio negli animali. Roma: Carrocci.

Darwin, Charles 1871. The Descent of Man and Selection in Relation to Sex. London: Murray.

- 1872. The Expression of Emotions in Man and Animals. London: Murray.

Delalande, François 1991. Le condotte musicali. Bologna: CLUEB.

Ditadi, Gino (ed.) 1994. I filosofi e gli animali. Este: Isonomia.

Dobzhansky, Theodor 1962. Mankind Evolving: The Evolution of the Human Species. New Haven: Yale University Press.

Eco, Umberto 1968. La struttura assente. Milano: Bompiani.

- 1975. Trattato di semiotica generale. Milano: Bompiani.

Giannatasio, Francesco 1992. Il concetto di musica. Roma: La Nuova Italia Scientifica.

Hartshorne, Charles 1973. Born to sing. Bloomington: Indiana University Press.

Jakobson, Roman 1963. Essais de linguistique générale. Paris: Minuit.

Kleiber, Georges 1990. La sémantique du prototype. Paris: Presses Universitaires de France.

Mâche, François-Bernard 1992. Music, Myth and Nature. New York: Harwood Academic Publishers.

Mainardi, Danilo (ed.) 1992. Dizionario di etologia. Torino: Einaudi.

Marconi, Luca 1996. Gli universali e il concetto di musica. Progetto Uomo Musica 9: 87-95.

Martinelli, Dario 1999. Il canto della megattera: Una musica bestiale. Musica/Realtà 60: 37-55.

Masson, Jeffrey M.; McCarthy, Susan 1996. Quando gli elefanti piangono: Sentimenti ed emozioni nella vita degli animali. Milano: Baldini \& Castoldi.

Mortenson, Joseph 1987. Whale Songs and Wasp Maps. New York: Duttons.

Nagel, Thomas 1974. What is it like to be a bat? Philosophical Review 83: 435-450.

Nattiez, Jean-Jacques 1977. Under what conditions can one speak of the universality of music? World of Music 19(1/2): 92-105.

Nettl, Bruno 1956. Music in primitive culture. Cambridge: Harvard University Press.

- 1977. On the question of universals. World of Music 19(1/2): 2-7.

Rosch, Eleanor; Barbara B. (eds.) 1978. Cognition and categorisation. Hillsdale: Lawrence Erlbaum Associates.

Schafer, Robert Murray 1985. Il paesaggio sonoro. Milano: Ricordi.

Sebeok, Thomas 1981. The play of musement. Bloomington: Indiana University Press. 


\section{Dario Martinelli}

Soriau, Eduard 1965. Le sens artistique des animaux. Parigi: Hachette.

Stefani, Gino 1985. Competenza musicale e cultura della pace. Bologna: CLUEB.

- 1997. Musica: Dall'esperienza alla teoria. Milano: Ricordi.

Szöke, Peter 1963. Ornitomuzikológia. Magyar Tudomány 9: 592-607.

Tagg, Philip 1987. Universal music and the case of the death. In: Pozzi, R. (ed.),

La musica come linguaggio universale. Firenze: Olschki, 227-266.

Wallin, Nils 1991. Biomusicology. Stuyvesant: Pendragon

\section{Методологии и проблемы в зоомузыкологии}

Статья представляет собой эскиз введения в зоомузыкологию как дисциплину, близко связанную с зоосемиотикой, сосредотачиваясь на имеющихся результатах и формулируя нуждающиеся в дальнейшей разработке проблемы. Анализ посвящен обнаружению границ и возможностей зоомузыкального исследования, выявлению проблемных тем и возможных методологий. Автор пытается определить и позицию данной дисциплины по отношению к другим областям исследования, особенно к этномузикологии.

\section{Metodoloogiad ja probleemid zoomusikoloogias}

Artikkel visandab esialgse sissejuhatuse zoomusikoloogiasse kui distsipliini, mis on lähedalt seotud zoosemiootikaga, keskendudes olemasolevatele tulemustele ja formuleerides edasist uurimist vajavaid probleeme. Analüüs on suunatud zoomusikoloogilise uurimise piirangutele ja potentsiaalile, problemaatilistele teemadele, võimalike metodoloogiate ringile ning autor püüab ka määratleda distsipliini positsiooni teiste uurimisvaldkondade, eriti etnomusikoloogia suhtes. 